\title{
Robert Venturi:
}

Denise R. Costanzo

The news of the death of Robert Venturi Jr [1] on 18 September 2018 at age 93 was not unexpected. He had gradually withdrawn from public life after his 2012 retirement. Nonetheless, his loss sent a ripple across the architecture world, and beyond. Not since the unexpected death of Zaha Hadid in 2016 has an architect received so many tributes from outside the field, in Venturi's case because of his exceptional familiarity. For decades, his name has been a fixture of visual arts and architecture survey courses, and his iconic house for his mother in the Philadelphia suburb of Chestnut Hill (1959-64), with its oversized pedimented facade and drawn-on eyebrow arch, appears in any list of the twentieth century's most influential buildings [2].' Venturi's similarly canonical first book, Complexity and Contradiction in Architecture of 1966 , offered a cheeky 'less is a bore' riposte to Mies, and a disorienting ride through a Mannerist-, modernist-, Tudor-, vernacular-, and Rococo-strewn landscape towards a gilded television antenna-as-acroterion. Venturi's heresies against the austere modernist box became pivot points that defined a new 'postmodern' era. He has been an architectural constant for over a halfcentury to the point where, for most of us, the Venturian age is the only architectural epoch we have ever known. Courtly and modest in person, known affectionately to many as 'Bob', his work was as polarising as it was famous, and aroused an inferno of critical ire.

Throughout his long career, Venturi's familiar name always embodied a dialectic. He produced not one, but two discourse-shifting books, adding the co-authored Learning from Las Vegas (1972) to Complexity and Contradiction. These writings gave Venturi unquestioned

\section{$1925-2018$}

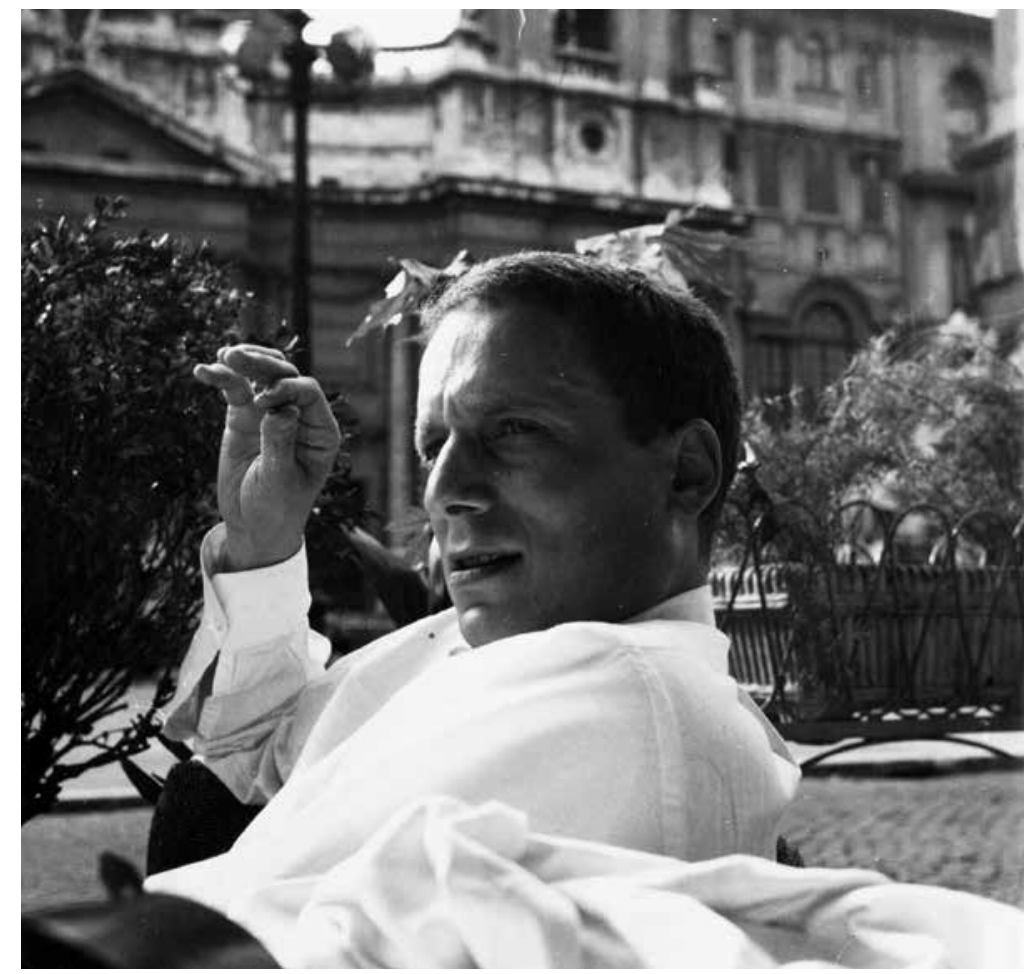

1. Robert Venturi in the Piazza Navona, Rome, c. 1955.

importance as a theoretician, yet the buildings that faithfully concretised those same theories were widely considered problematic. He consistently resisted the 'postmodern' label despite being the movement's most famous standard-bearer. Even the apparent triumph of his 1991 Pritzker Prize continues to generate heated controversy. For nearly any architectural ideal, one side of Venturi fulfills it, while another subverts it. That his legacy is permeated with such profound ambivalence is poetic, given his famous celebration of Mannerist ambiguity. But is this something to lament, or to celebrate?

\section{Ambitious individual/ enlightened partner}

Any discussion of Venturi should address the minor yet momentous issue of pronouns. Many of his most celebrated achievements, including the early works that secured his prominence, are rightly discussed in the singular 'he'. Much of Venturi's success can be attributed to remarkable individual effort, vision, and determination. Venturi studied architecture at Princeton (BA 1947, MFA 1950), a modern design programme embedded within a department of art history. Upon graduation he worked for Eero Saarinen then, after returning to Philadelphia for family reasons, for 
Louis I. Kahn, whom he venerated. Meanwhile, Venturi applied three times for a Rome Prize fellowship at the American Academy, which he finally won in 1954 . He seized that opportunity to travel, absorb, and reflect with rare purpose, then returned to Philadelphia to launch a fledgling practice in 1957. During this period, he distilled ideas while painstakingly designing and redesigning his mother's referentially dense house, teaching at the University of Pennsylvania, and writing and rewriting his first book, the outcome of over a decade of intense contemplation. Venturi poured his ambition into works that positioned him to succeed the prior generation's modernist heroes by embracing an ironic 'anti-heroic' mode.

As Venturi ascended to architectural immortality in 1966, however, 'he' became a 'they'. That year he completed his first book, returned to Rome as an American Academy resident, then went to Las Vegas on his first pilgrimage to Sin City with Denise Scott Brown. This journey generated a series of joint projects:Yale studios he and Scott Brown co-taught with Steven Izenour, and the resulting book they co-authored. Thereafter, Venturi's famous name was tied to Scott Brown's, his partner in work and in life (the couple married in 1967) for over fifty years [3]. In practice, Venturi had always joined his name with a partner's (John Rauch from 1964), although as his teaching and writing made Venturi's name more visible, critics made it a metonym for the firm's collective work.

Venturi's partnership with Scott Brown, which began after a Penn faculty meeting in 1960, was of a different order. Besides its personal side, it would be his longest and most multifaced collaboration: intellectual, creative, and authorial. Scott Brown's own forceful critical and creative voice was developed in teaching, research, and writing. She joined Venturi and Rauch as a partner in 1969 and, although her name did not appear on the firm's letterhead until 1980, the names Venturi and Scott Brown became visibly linked through dozens of co-authored publications.

Professionally, they were seen as a creative pair. Yet unlike Charles and Ray Eames, and Alison and Peter Smithson, the field's other midcentury power couples, Scott Brown was often considered an addendum to Venturi's once-independent career, a solo act turned duet. This

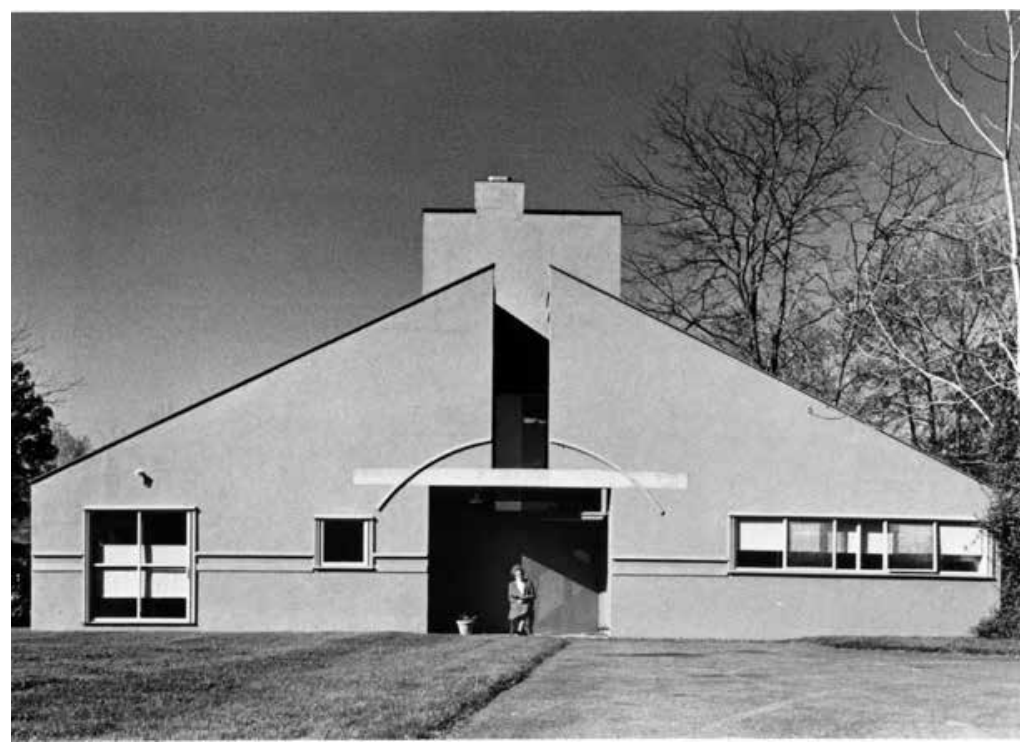

2. Venturi and Rauch, Vanna Venturi House, Chestnut Hill, PA (1959-64). Photo by Rollin LaFrance

introduced the question of clarifying which of 'his' ideas and projects were in fact 'theirs'.

The shifting pronouns were inconsistent, contested, and destabilising. Work bearing Venturi's name was often described as 'his', no matter its authorship. ${ }^{2} \mathrm{~A}$ plural subject was not necessarily accurate either, as 'Venturi and Scott Brown' (occasionally 'the Venturis') could occlude other authors. Perennial issues of creative attribution intersected with newer concerns about gender equity, described by Scott Brown in a pioneering feminist critique of the profession. ${ }^{3}$ Venturi's agency on this issue has received less attention, but is crucial. It remains rare for any architect who attains star status individually to step aside and share the spotlight with a partner; rarer still for that partner to be a woman. Venturi's choice to become a public 'they' can be seen as enlightened, a repudiation of the entrenched preference for the sole (male) auteur, and an overt embrace of complex collective creativity. Others, especially those who dislike their joint work, might instead accuse him of permitting his promising individual path to be hijacked and derailed. One Venturi doggedly pursued his name's immortality as individual artistintellectual, while another willingly downgraded his 'Great Name' to one half of a partnership. Either can be seen as heroic, or as unfortunate.

Venturi's acceptance of the Pritzker is disruptive for both. The announcement and jury citation focused squarely on his earliest, individual achievement: 'saving modern architecture from itself' with Complexity and Contradiction, his decades of joint work with Scott Brown acknowledged only as a coda. ${ }^{4}$ Despite recent campaigns to bestow retrospective credit on Scott Brown, that organisation has held fast. Venturi kept the Pritzker, but refused to accept the AIA Gold Medal until it would be awarded jointly to him and Scott Brown in 2016, a first for that honour (the first Pritzker awarded to a partnership was in 2001). The first word of that announcement is 'collaborators'; it emphasises 'their' work, not 'his', contrasting recognitions that affirm how Venturi fulfills two competing models of the architect.

\section{Difficult whole/decorated shed}

Venturi's double identity extends to his work, which includes the two most influential architectural texts of the late twentieth century. The Pritzker jury affirmed the famous, hyperbolic, and partisan claim from Vincent Scully's introduction to Complexity and Contradiction: that Venturi's first book was the field's most important since Le Corbusier's Vers une architecture of 1923. The AIA Gold Medal jury, in contrast, saw Complexity and Contradiction and Learning from Las Vegas as having equivalent significance. Regardless, the two texts only vie with each other for the position of successor to Le Corbusier's modernist gospel. Both also deploy many of that foundational polemic's strategies, using provocative declarations and surprising juxtapositions of images 
to subvert entrenched dogmas and redirect architects' eyes towards newly relevant sources of inspiration.

How the books diverge is obvious from their covers. Complexity and Contradiction's image-free first edition and the second, featuring Michelangelo's Porta Pia, are both dignified foils for Tanya, the 'Tan Hawaiian' odalisque reclining across Learning from Las Vegas's freeway billboard. This contrast sets up distinct projects. Complexity and Contradiction is a work of profound connoisseurship, a visual and conceptual demonstration of the nuanced and difficult approach to composition that Venturi sees as fundamental to architectural quality. Famous for its promiscuous use of historic exemplars, the book is not a history; it offers no chronology or context for any building's significance outside the author's formal preoccupations. Venturi does, however, leverage the implicit authority of canonical works just as Le Corbusier used the Acropolis and Michelangelo. While Complexity and Contradiction was a strategically 'gentle', self-consciously erudite manifesto, the flashier, brasher Learning from Las Vegas emulated Le Corbusier's avant-garde combativeness. The book's 'nonjudgmental' approach to investigating the mechanics of the automotive city's commercial strip was as defiant as Vers une architecture's use of turbines and airplane cockpits to define the machine age. Both took the seemingly banal products of a new era seriously, just as worthy of the architect's attention as Rome.

The books directed their efforts towards related but distinct aims. Complexity and Contradiction held out an ideal of design synthesis through the 'Difficult Whole', while Learning from Las Vegas offered readers the dialectic of Duck and Decorated Shed, both of which maintain architecture's competing imperatives in dynamic suspension. Both books are about context but, for Complexity and Contradiction, this is disciplinary, while in Learning from Las Vegas it is the late-capitalist built environment in which that discipline must intervene. Both present a profound architectural challenge: the first book with a standard of success that is difficult for any architect to achieve; the second with a vision of the architect's role that is difficult to accept. been more revered, Learning from Las Vegas more controversial. Critics saw the latter's embrace of the everyday as a capitulation to corporate interests under the guise of populism. ${ }^{5}$ Despite this,

Venturi's first book was overshadowed by its successor in important ways. If Complexity and Contradiction was the book everyone knew 'about', Learning from Las Vegas was more frequently read; its more accessible referents, overt provocations, and 'edgy' tone are more amenable to both introductory students and sophisticated, critical theory-based analyses. ${ }^{6}$ The pendulum may swing the other way, as Complexity and Contradiction's fiftieth anniversary in 2016 has inspired return visits to a book that remains more familiar than understood.

If the books' differences reinforce a tale of two authorial Venturis, early (solo) and late (conjoined), this must be tempered by their many points of continuity.
Complexity and Contradiction has
Before Venturi met Scott Brown, he was already interested in pop culture, urbanism, visual communication, Rome, and context. Learning from Las Vegas is no less a 'Venturian' book than Complexity and Contradiction; if it took his ideas in a more realist, less idealist direction, it was one he chose. He continued to write under his name alone and in co-authorship with Scott Brown, essays, many later compiled into book-length collections. ${ }^{8}$ If his (their) ideas and terminology evolved into the 'flexible loft' and driving concerns remained consistent. As a theoretician, Venturi confronted the persistent architectural challenge of how to make practical, meaningful buildings in two different ways: as a pragmatist who accepted the limits of real-world building, and as an idealist who measured his work against the highest aspirations and achievements of his discipline. producing dozens of lectures and 'mitten-glove' analogy, his (their)

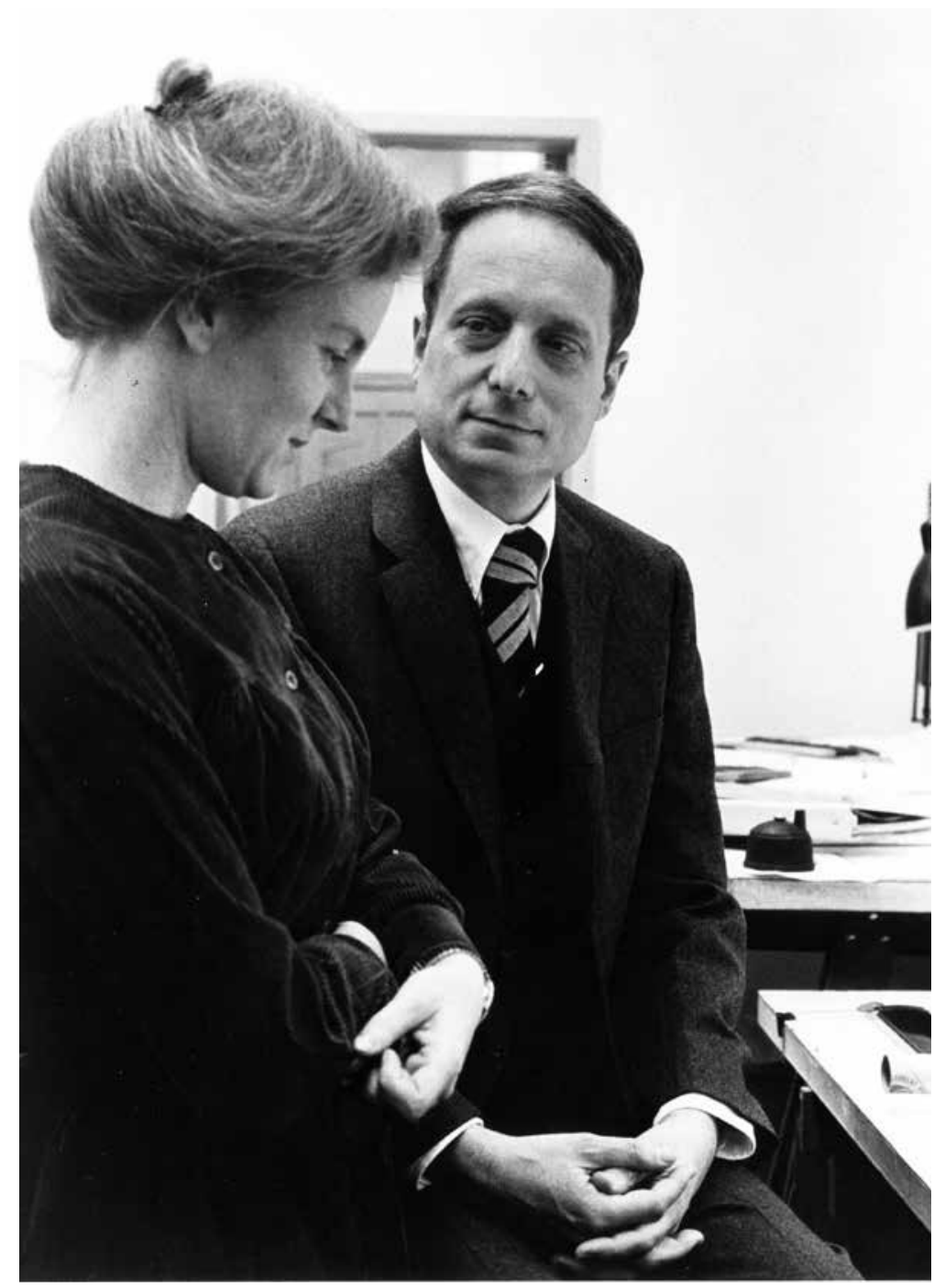

3. Denise Scott Brown and Robert Venturi, c. 1968. Photo by George Pohl 


\section{Laudable theory| \\ lamentable practice}

Theory was not a phase in Venturi's career, but its consistent substrate. Another constant was that, as a theoretician, in whichever mode, he was consistently accorded respect; even his harshest critics acknowledged the force and significance of his ideas. As an architect, however, his reputation was more uneven. During the four years he spent designing his mother's house, Venturi abandoned his hero Kahn's poetic volumes to produce cerebral prose. He compressed ever more references into a less coherent form, resulting in a clever stucco box that privileges image and formal tension over celebration of structural expression, phenomenal materiality, or evocative space. Venturi's buildings continued in this same vein thereafter, combining multivalent forms with communicative envelopes that convey eye-catching messages for a fast-moving, multimedia age. No matter the material, these surfaces were detailed to appear maximally flat and insubstantial, resulting in buildings that can look like fullscale models [4]. Many who admire the seriousness of Venturi's conceptual work recoil with distaste at the way his buildings combine intentional superficiality with clever, but often cartoonish, visual citations.

A divided response, however common, ignores the fact that Venturi's buildings reflected a staunch adherence to his theories. Privileging his ideas over his architecture also inverts his own priorities, because Venturi made building his greatest priority throughout his career. He taught (first at Penn, then at Yale) and wrote strategically to establish himself in his field and advance his ideas. Whereas contemporaries like Michael Graves and Peter Eisenman made academia a constant anchor for their careers, Venturi stopped teaching after $1970 .{ }^{9}$ Once his practice was on a firm footing, his primary architectural commitment was designing buildings for clients. Learning from Las Vegas's appeal for architects to be creatively engaged with the real world was not mere posturing, but a central concern throughout Venturi's career. Architectural discourse still mattered deeply to him; besides his ongoing writings, his firm kept a running bibliography of writings by others about its work. ${ }^{10}$ Yet, for
Venturi, architectural ideas served the cause of making buildings, rather than the reverse.

This inverts the notion that 'serious' architecture stands at a certain remove from the sordid world of commercial practice. Such a position would not be a comfortable one for Venturi, who spent his first decades as an architect managing his family's wholesale produce business in parallel. He understood all-too-well how creative production fitted into the American economy; his career was an embodiment of the 'architectural accommodation' described in Complexity and Contradiction. He still fulfilled his ambition to be an architect-asintellectual who offers challenging, uncomfortable ideas that reframe the world of intentional building; as well as architect-as-maker who produces meaningful, if aesthetically and culturally disconcerting, buildings that fulfill these ideas. Venturi demonstrates the power of theory to construct architectural immortality, a lesson as old as Vitruvius. He also demonstrates a dogged commitment to the idea that the summa of an architect's career is not the conceptual realm of words, but the concrete one of walls.

\section{Postmodernist/Modernist}

Venturi's theory and practice together contribute to his reputation as the father of architectural postmodernism, an attribution he consistently renounced (calling it at best a 'bastard' child).$^{11}$ His complex relationship with this label is not only a central component of the Venturian legacy, but an increasingly relevant issue amid a purported postmodern 'revival'. ${ }^{12}$ This category is a container for divergent ideas and aims across fields, one that remains notoriously confounding and unwieldly. Despite this, Venturi was unquestionably fundamental to its extension to architecture. His earliest projects and first book provided visual expression, conceptual coherence, and critical impetus to percolating reactions to modernist orthodoxy, a fulcrum for a wider revolt. When Charles Jencks summarised the movement in 1977 , his idea of 'double-coding' echoed Complexity and Contradiction's categories of 'both/and' and 'double-functioning elements', as well as Venturi's promotion of design that speaks parallel visual and cultural languages by interweaving publicly legible architectural imagery with erudite formal citations. ${ }^{13}$ If Learning from Las Vegas varied these ingredients' proportions - more urban sociology and pop culture, less high seriousness - its recipe was much the same. Venturi and Scott Brown produced 'second-glance' architecture that spoke generally familiar visual codes, while offering architectural polyglots more to discover. However much they may have disliked the label, it was one Venturi and Scott Brown leveraged by associating their work with contemporaries creating similarly communicative, vibrant, intricately referential designs. Their names and work were indelibly conjoined with other postmodern protagonists in such key events as the first Venice Architecture Biennale's 'Strada Novissima' in $1980 .{ }^{14}$ Investigations of the origins and early contours of Venturi's thinking often began as or became archaeologies of postmodernism; the two overlap that directly. ${ }^{15}$

If Venturi and Scott Brown's disavowals of the association with a broader postmodernism were rather disingenuous, they were also justified. His formalism stands apart from that of the equally exuberant, colorful, history-andpop-quoting work of Charles Moore, or Graves's painterly play of referential volumes. What most distinguishes their work is its modernist ethos. Venturi and Scott Brown even referred to themselves as 'functionalists', an even more incongruous label for their buildings. What makes both adjectives potentially legitimate was Venturi and Scott Brown's definition of 'function'. For them, it encompassed the whole Vitruvian triad, not just structure and utility, with venustas understood as the visual expression of a building's competing, conflicting qualities. ${ }^{16}$

Venturi's off-putting designs eschewed phenomenal poeisis in favour of transparent expressions of the way modern buildings combine image, purpose, and construction. His buildings appear insubstantial because they are: standard construction consisting of structural and mechanical systems wrapped with a nonstructural enclosing envelope. For any veneer to suggest solidity is dishonest. In this, they were as rigorous as Mies. If Venturi's and 


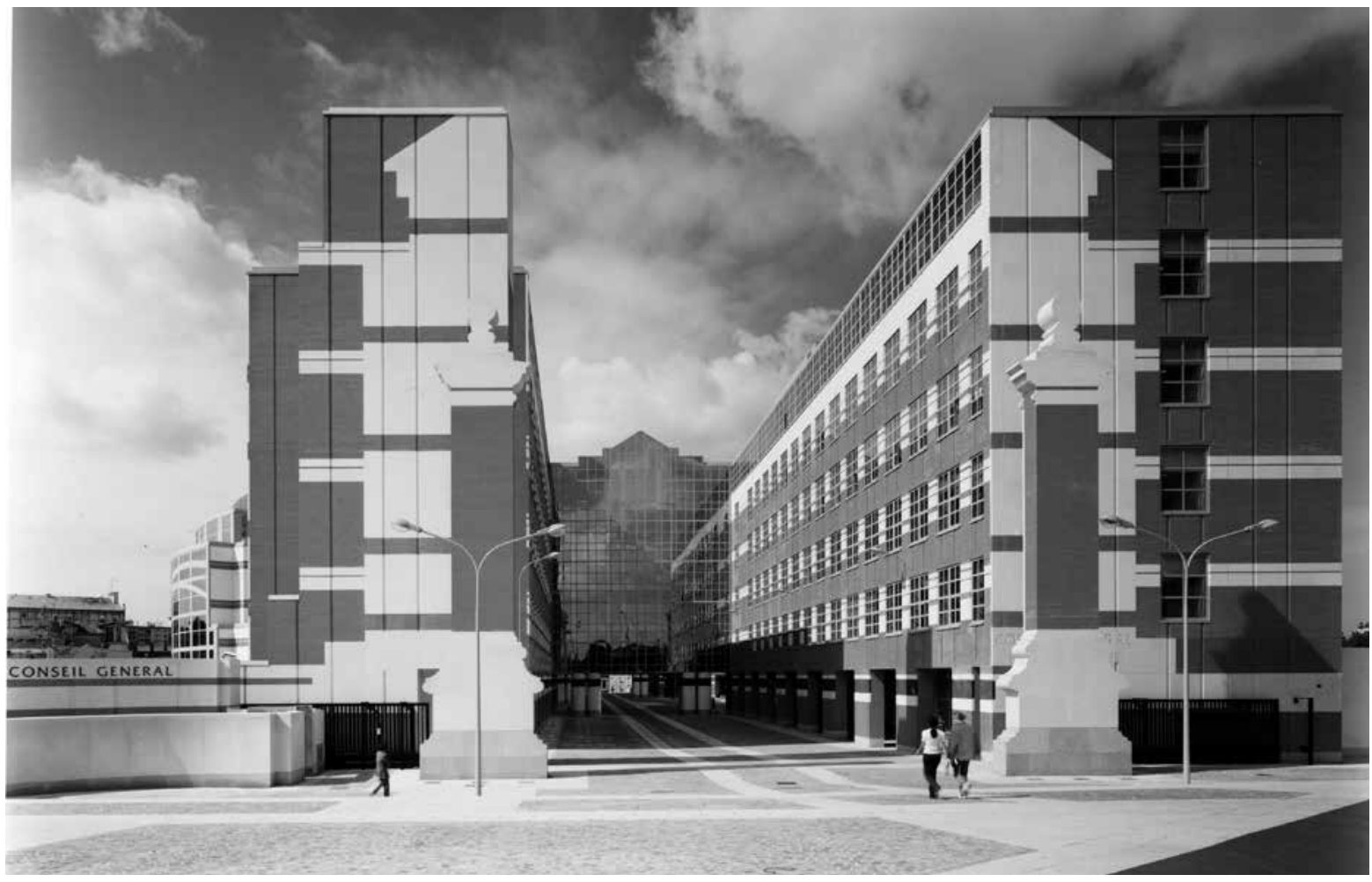

4. Exterior view, Venturi, Scott Brown and Associates, Hôtel du Département de la Haute-Garônne, Toulouse, France (1990-9).

Scott Brown's modernism looks entirely different from Mies's, with its colossal floral patterns and cookie cut-out columns, it was meant as an indexical signifier of their own modern moment, an expression of the many jobs that architecture performs within a late capitalist culture. If 'standard' architectural postmodernism reacted to an overly laconic modernism, Venturi and Scott Brown might be considered 'counter-reformation' modernists, who returned to the movement's founding principles and updated them to speak to an exuberantly multi-media age.

Venturi's use of weightless surfaces to simultaneously critique and fulfill modernist orthodoxy has more in common with a contemporary whose work had no place on the Strada Novissima: Peter Eisenman. Eisenman's early 'cardboard house' series manipulated a very different set of referents (cubes, grids, and other enigmatic signifiers) in pursuit of autonomous abstraction for an elite, exclusive audience. Despite their work's many contrasts, both Venturi and Eisenman shared one formalist project: to construct intricate texts that capture contemporary culture's multivalence and instability. Venturi and Eisenman are thus equally 'postmodern' in the sense found in critical theory: their work grapples with the irresolvable ambiguities of language. Moreover, both believed that resolving architecture's infinite contradictions is less important than being honest about them. Here, too, is another Venturian paradox. He was a modernist who sought to apply that movement's principles as deeply - and as superficially - as possible, and also a postmodernist in more than one sense. He embraced architecture as a medium for messages and memories, but refused to think about the problem of meaning in a facile way. By facing the inevitable incoherencies of any 'honest' architecture, he made himself doubly postmodern, despite himself.

\section{Reactionary/progressive}

Venturi's half-century of prominence means that most architectural scholars have an image of who he was, and opinions about his work. Whatever our picture of Venturi looks like, it is never the full story. Our understanding of him is usually just as correct as its opposite. This instability drives much of his appeal as a research subject. He offers a compelling intellectual puzzle, whose painfully clever works can repel the eye yet still inspire admiration.
A final, crucial question is: what values did his cleverness serve? Venturi's faith in architectural tradition made him a paradigmatic conservative. He valued academicism, almost singlehandedly restoring the tattered bridge connecting American architects to Rome, and accepted that architecture was a commodity subject to the laws of the capitalist marketplace. He also believed in an aristocracy of images and ideas, that some works and concepts carry deeper significance than others, and that an incisive, properly trained eye can see architectural greatness.

But the tradition Venturi embraced was Janus-faced: his antiutopian 'conservatism' fulfilled the modernist avant-garde's demand for revolutionary change. His elitist tendencies were tempered by populism, addressing a far broader public with his work than most architects of his day. Within his own office, he led a quiet revolution that made space for new visions and voices, and embodied a model of architectural success that focused on not just espousing ideas, but building them. Was Venturi a progressive? Or a reactionary? In this, too, he was 'both/and', of course. His lack of ideological purity should not be mistaken for an absence of integrity, but seen rather as a 
commitment to keep the discipline tied to the messy vitality of the real. This makes his ambivalence worthy of our respect. Venturi's legacy of complexities and contradictions deserves, and can withstand, whatever questions, scepticism, frustration, reverence, or indifference we might bring.

Robert Venturi is survived by his wife Denise Scott Brown and their son James Venturi.

Denise R. Costanzo is Assistant Professor of Architecture and Art History at The Pennsylvania State University (University Park, Pennsylvania, USA). She is the author of What Architecture Means: Connecting Ideas and Design (Routledge, 2016). Her essays on Venturi have appeared in the Journal of Architectural Education and the Journal of Architecture, and on Venturi and Scott Brown as 'functionalists' in Wolkenkuckucksheim: internationale Zeitschrift fur Theorie und Wissenschaft der Architektur| Cloud-Cuckoo-Land: International Journal of Architectural Theory. These analyses are extensions of her research into the multinational postSecond World War Rome Prize, the subject of her current book project.

\section{Notes}

1. Frederick Schwartz, Mother's House: The Evolution of Vanna Venturi's House in Chestnut Hill (New York: Rizzoli, 1992).

2. 'Robert Venturi's Response at the Pritzker Prize Award Ceremony at the Piazza de Iturbide, Mexico City, May 16, 1991', in Robert Venturi, Iconography and Electronics upon a Generic Architecture: A View from the Drafting Room (Cambridge, MA: The MIT Press, 1998).

3. Denise Scott Brown, 'Room at the Top? Sexism and the Star System in Architecture', in Architecture: A Place for Women, ed. by Ellen Perry Berkeley and Matilda McQuaid (Washington, DC: Smithsonian Institution Press, 1989), written 1975.

4. <https://www.pritzkerprize.com/ laureates/1991> [accessed 16 November 2018].

5. Kenneth Frampton, Modern Architecture: A Critical History (London: Thames \& Hudson, 2007), p. 291.

6. Aron Vinegar and Michael Golec, eds, Relearning from Las Vegas (Minneapolis: University of Minnesota Press, 2009).

7. For a review of one anniversary event, see: D. Costanzo, 'Learning from Venturi: Complexity and Contradiction at 50', arq, 20:4 (2016),

293-6.

8. Iconography and Electronics is sole-authored; Venturi and Scott Brown co-authored A View from the Campidoglio: Selected Essays 1953-1984 (New York: Harper \& Row, 1984) and Architecture as Signs and Systems: For a Mannerist Time (Cambridge, MA: Harvard University Press, 2004).

9. Scott Brown taught a Penn studio as a visiting professor in $1982-3$; Diane Minnite 'Chronology', in Out of the Ordinary: Robert Venturi, Denise Scott Brown and Associates: Architecture Urbanism Design, ed. by David Brownlee, David De Long, and Kathryn Hiesinger (Philadelphia: Philadelphia Museum of Art, 2001), p. 249. 10. A bibliograpy is included in A View from the Campidoglio and Architecture as Signs and Systems, and remains available on the VSBA website <https://www.vsba. com/who-we-are/bibliography/> [accessed 23 November 2018].

11. Robert Venturi, 'I Am Not Now nor Have I Ever Been A Postmodernist', Architecture, May (2001).

12. Contributing texts include Terry Farrell and Adam Nathaniel Furman, Revisiting Postmodernism (Newcastle upon Tyne: RIBA Publishing, 2017); Sean Griffiths, 'Now Is Not the Time to be Indulging in Postmodern Revivalism', DeZeen, 30 October (2017); and Giacomo Pala, 'Postmodern Post-Mortem: Why We Need to Stop Using Architecture's Most Misunderstood Word', ArchDaily, 11 January, 2018.

13. Charles Jencks, The Language of Post-Modern Architecture (New York: Rizzoli, 1977)

14. Léa-Catherine Szacka, Exhibiting the Postmodern: The 1980 Venice Architecture Biennale (Venice: Marsilio, 2016).

15. Martino Stierli, 'In the Academy's Garden: Robert Venturi, the Grand Tour and the Revision of Modern Architecture', AA Files, 56 (2007), $4^{2-} 55$.

16. D. Costanzo, 'Venturi and Scott Brown as Functionalists: Venustas and the Decorated Shed', Wolkenkuckucksheim: internationale Zeitschrift fur Theorie und Wissenschaft der Architektur | CloudCuckoo-Land. International Journal of Architectural Theory, 17 (2012), 9-25.

\section{Illustration credits}

arq gratefully acknowledges:

Venturi Scott Brown Collection, The Architectural Archives, University of Pennsylvania by the gift of Robert Venturi and Denise Scott Brown: 1-4 